\title{
Does Iron Release from Transferrin Involve a Reductive Process?
}

\section{Fadi Bou-Abdallah*}

Department of Chemistry, State University of New York at Potsdam, 44 Pierrepont Avenue, Potsdam, NY 13676, USA

With the exception of a few members of the genus Lactobacillus and some strains of Bacillus, iron is required for all living organisms. It is the major trace metal in the body and an essential element, for the proper function of many proteins and enzymes. However, low molecular weight iron (sometimes called free-iron or labile iron) is potentially toxic to cells because of the easy inter-conversion between ferrous $\left(\mathrm{Fe}^{2+}\right)$ and ferric $\left(\mathrm{Fe}^{3+}\right)$ ions, and its tendency to be involved in oxygen redox chemistry. To overcome this problem, iron-dependent organisms, from Archaea to man, have developed a number of strategies and mechanisms to regulate its uptake and release, in order to prevent the formation of damaging free radical reactions. One of the major proteins involved in iron homeostasis is serum-transferrin. At neutral $\mathrm{pH}$, serum iron-loaded transferrin binds with high affinity to the specific transferrin receptor (TfR) on the cell surface; the Tf/TfR complex is then internalized into an endosome, where iron is released at the acidic $\mathrm{pH}$ of $\sim 5.6$. The iron-free protein remains attached to its receptor in the acidic environment, until it is recycled to the cell surface, where it is released for another cycle of receptor-mediated endocytosis. The uptake and release of iron by transferrin, and the interaction of the iron-loaded transferrin with the transferrin receptor, are key cellular processes that occur during the normal course of iron metabolism. Understanding the thermodynamics of these interactions is important for iron homeostasis, since the physiological requirement of iron must be appropriately maintained, to avoid iron-related diseases. Despite decades of research and the development of a number of chemical, biochemical and biophysical techniques, the mechanism of iron release from each lobe of transferrin within the endosome, is still not fully understood. All in-vitro studies are at best speculative, and cannot be directly applied to describe the mechanism of iron release from cells, since the precise endosomal milieu is unknown.

In general, the specific recognition of ferric ions $\mathrm{Fe}^{3+}$ (and not ferrous ions $\mathrm{Fe}^{2+}$ ) requires the presence of the synergistic physiological anion (carbonate or bicarbonate), although other synergistic anions have been shown to bind as well [1]. While transferrin is abundant in the circulation $(\sim 40 \mu \mathrm{M}$ or $\sim 3 \mathrm{mg} / \mathrm{ml})$, only about $30 \%$ is saturated with iron in normal human serum. The avid binding protects $\mathrm{Fe}(\mathrm{III})$ from hydrolysis at physiological pHand renders it unavailable for radical formation via Fenton reactions. The fact that only one third of the Tf molecules are saturated with iron, suggests that other metals can also bind and be transported. A number of metal ions (up to 40 different metal ions) have been shown to bind to transferrin [2-10], in the presence of different synergistic anions such as bicarbonate, oxalate or nitrilotriacetate and include $\mathrm{Mn}(\mathrm{II}), \mathrm{Cu}(\mathrm{II}), \mathrm{Ni}(\mathrm{II}), \mathrm{Cd}(\mathrm{II})$, VO(II), Zn(II), Cr(III), Co(III), Ru(III), Bi(III), Ga(III), In(III), Al(III), Tl(III), La(III), Ce(III), UO2(II), Nd(III), Sm(III) and Gd(III). Some of these metal ions are toxic with perhaps no physiological significance or benefits. However, since hetero-metal transferrin complexes are still recognized by the transferrin receptor, such binding may play an important role in the transport and delivery of various metalcontaining compounds, for diagnosis and therapy. For instance, platinum complexes are used in cancer chemotherapy, gold compounds in the treatment of arthritis, gallium, indium and aluminum as medical diagnostic radioisotopes, and bismuth, ruthenium and titanium are used as anti-ulcer medication $[11,12]$.
Recent kinetic studies have suggested an important role for the transferrin receptor, in modulating the mobilization of iron from the $\mathrm{N}$ and the C-lobes of transferrin $[13,14]$. In support of this idea, an earlier investigation has reported a critical effect of the transferrin receptor on the redox properties of human transferrin, and the subsequent release of iron from the Tf/TfR complex [15]. However, other studies [16,17] have shown that, at the $\mathrm{pH}$ of the endosome, the redox potential of the iron in holotransferrin bound to the transferrin receptor, is within the range of endosomal reductases, making the reduction of $\mathrm{Fe}$ (III) to $\mathrm{Fe}(\mathrm{II})$, a plausible scenario for Fe release from Tf. Towards this end, a number of laboratories have attempted to determine the reduction potential of iron in transferrin, under different experimental conditions and data manipulation, and have reported a range of values, anywhere from - $140 \mathrm{mV}$ to $-530 \mathrm{mV}$ [18-22]. Interestingly, more than two decades ago, a model for iron mobilization from transferrin has been proposed, to involve intravesicular acidification followed by Fe(III) reduction by a membrane oxidoreductase, and an Fe(II) transporter system for iron translocation [23]. Note that once inside the cell, the acidification of the endosome (down to $\mathrm{pH} \sim 5.6$ ) weakens the affinity of iron to transferrin, leading to its release [2]. Thus, it is still unknown, what is responsible for iron removal from transferrin at the acidic $\mathrm{pH}$ of the endosome, and whether reduction of $\mathrm{Fe}$ (III)-bound transferrin occurs before, or after iron is released from the Tf/TfR complex, before it is transported out of the endocytic vesicle.

Interestingly, the affinity of $\mathrm{Fe}(\mathrm{II})$ to transferrin has not been determined, and isothermal titration calorimetry (ITC) is one excellent technique and a direct way to investigate the thermodynamics of this interaction. Ferrous ion is kinetically more labile than ferric ions, and the affinity of $\mathrm{Tf}$ for $\mathrm{Fe}(\mathrm{II})$ is estimated to be at least 17 to 18 orders of magnitude lower than that of $\mathrm{Fe}(\mathrm{III})$, consistent with a reductive release of iron from transferrin [18]. Preliminary ITC measurements from our laboratory of $\mathrm{Fe}(\mathrm{II})$ binding to $\mathrm{Tf}$, under anaerobic conditions and $\mathrm{pH} 7.0$, showed binding affinities of $\mathrm{Fe}(\mathrm{II})$ to $\mathrm{Tf}$ in the range of $10^{6}$ $10^{7} \mathrm{M}^{-1}$, in accordance with an earlier thermodynamic study based on zinc binding to transferrin and a linear free-energy relationship [24] These $\mathrm{Fe}(\mathrm{II})$ affinity values are much higher than previous indirect estimates of $10^{3} \mathrm{M}^{-1}$ [25] and will profoundly influence the $\mathrm{Fe}^{3+}$ or $\mathrm{Fe}^{2+}$ redox potential of the iron loaded human serum transferrin, and consequently the possibility of iron release from transferrin via redox reactions. Therefore, a direct determination of the binding affinity of $\mathrm{Fe}(\mathrm{II})$ to $\mathrm{Tf}$ (in the presence and absence of the transferrin receptor) is of considerable importance, to better estimate the reduction potential

${ }^{*}$ Corresponding author: Fadi Bou-Abdallah, State University of New York at Potsdam, Potsdam, NY, USA, Tel: 01315267 2268; Fax: 01315267 3170; E-mail: bouabdf@potsdam.edu

Received September 09, 2012; Accepted September 11, 2012; Published September 13, 2012

Citation: Bou-Abdallah F (2012) Does Iron Release from Transferrin Involve Reductive Process? Bioenergetics 1:e111. doi:10.4172/2167-7662.1000e111

Copyright: (c) 2012 Xie Z. This is an open-access article distributed under the terms of the Creative Commons Attribution License, which permits unrestricted use, distribution, and reproduction in any medium, provided the original author and source are credited. 
Citation: Bou-Abdallah F (2012) Does Iron Release from Transferrin Involve a Reductive Process? Bioenergetics 1:e111. doi:10.4172/2167$7662.1000 \mathrm{e} 111$

of $\mathrm{Fe}(\mathrm{III})$ bound to $\mathrm{Tf}$ and provide insights into the reductive release of iron from transferrin, at the acidic $\mathrm{pH}$ of the endosome.

\section{References}

1. Aisen P, Leibman A, Zweier J (1978) Stoichiometric and site characteristics of the binding of iron to human transferin. J Biol Chem 253: 1930-1937.

2. Sargent PJ, Farnaud S, Evans RW (2005) Structure/function overview of proteins involved in iron storage and transport. Curr Med Chem 12: 2683-2693.

3. Hemadi M, Miquel G, Kahn PH, El Hage Chahine JM (2003) Aluminum exchange between citrate and human serum transferrin and interaction with transferrin receptor 1. Biochemistry 42: 3120-3130.

4. Welch S (1992) Transferrin: The Iron Carrier. Taylor \& Francis, CRC, UK.

5. Hemadi M, Kahn PH, Miquel G, El Hage Chahine JM (2004) Transferrin's mechanism of interaction with receptor 1 . Biochemistry 43: 1736-1745.

6. Miquel G, Nekaa T, Kahn PH, Hemadi M, El Hage Chahine JM (2004) Mechanism of formation of the complex between transferrin and bismuth, and interaction with transferrin receptor 1. Biochemistry 43: 14722-14731.

7. Chikh Z, Ha-Duong NT, Miquel G, El Hage Chahine JM (2007) Gallium uptake by transferrin and interaction with receptor 1. J Biol Inorg Chem 12: 90-100.

8. Ha-Duong NT, Hemadi M, Chikh Z, Chahine JM (2008) Kinetics and thermodynamics of metal-loaded transferrins: transferrin receptor 1 interactions. Biochem Soc Trans 36: 1422-1426.

9. Chikh Z, Hemadi M, Miquel G, Ha-Duong NT, El Hage Chahine JM (2008) Cobalt and the iron acquisition pathway: competition towards interaction with receptor 1. J Mol Biol 380: 900-916.

10. Hemadi M, Ha-Duong NT, Plantevin S, Vidaud C, El Hage Chahine JM (2010) Can uranium follow the iron-acquisition pathway? Interaction of uranyl-loaded transferrin with receptor 1. J Biol Inorg Chem 15: 497-504.

11. Sun H, Li H, Sadler PJ (1999) Transferrin as a metal ion mediator. Chem Rev 99: 2817-2842.

12. Qian ZM, Li H, Sun H, Ho K (2002) Targeted drug delivery via the transferrin receptor-mediated endocytosis pathway. Pharmacol Rev 54: 561-587.

13. Steere AN, Chasteen ND, Miller BF, Smith VC, MacGillivray RT, et al. (2012)
Structure-based mutagenesis reveals critical residues in the transferrin receptor participating in the mechanism of $\mathrm{pH}$-induced release of iron from human serum transferrin. Biochemistry 51: 2113-2121.

14. Eckenroth BE, Steere AN, Chasteen ND, Everse SJ, Mason AB (2011) How the binding of human transferrin primes the transferrin receptor potentiating iron release at endosomal pH. Proc Natl Acad Sci U S A 108: 13089-13094.

15. Nunez MT, Gaete V, Watkins JA, Glass J (1990) Mobilization of iron from endocytic vesicles. The effects of acidification and reduction. J Biol Chem 265 6688-6692.

16. McKie AT (2005) A ferrireductase fills the gap in the transferrin cycle. Nat Genet 37: 1159-1160

17. Ohgami RS, Campagna DR, Greer EL, Antiochos B, McDonald A, et al. (2005) Identification of a ferrireductase required for efficient transferrin-dependent iron uptake in erythroid cells. Nat Genet 37: 1264-1269.

18. Harris WR (1986) Estimation of the ferrous-transferrin binding constants based on thermodynamic studies of nickel (II)-transferrin. J Inorg Biochem 27: 41-52.

19. Harris DC, Rinehart AL, Hereld D, Schwartz RW, Burke FP, et al. (1985) Reduction potential of iron in transferrin. Biochim Biophys Acta 838: 295-301.

20. Kretchmar SA, Reyes ZE, Raymond KN (1988) The spectroelectrochemical determination of the reduction potential of diferric serum transferrin. Biochim Biophys Acta 956: 85-94

21. Kraiter DC, Zak O, Aisen P, Crumbliss Al (1998) A determination of the reduction potentials for diferric and $\mathrm{C}$ - and $\mathrm{N}$-lobe monoferric transferrins at endosomal pH (5.8). Inorg Chem 37: 964-968.

22. Taboy CH, Vaughan KG, Mietzner TA, Aisen P, Crumbliss Al (2001) $\mathrm{Fe}^{3+}$ coordination and redox properties of a bacterial transferrin. J Biol Chem 276 2719-2724.

23. Dhungana S, Taboy CH, Zak O, Larvie M, Crumbliss AL, et al. (2004) Redox properties of human transferrin bound to its receptor. Biochemistry 43: 205-209.

24. Harris WR (1983) Thermodynamic binding constants of the zinc-human serum transferrin complex. Biochemistry 22: 3920-3926.

25. Kojima N, Bates GW (1981) The formation of $\mathrm{Fe}^{3+}$-transferrin- $\mathrm{CO}_{3}{ }^{2}$-via the binding and oxidation of $\mathrm{Fe}^{2+}$. J Biol Chem 256: 12034-12039. 